\title{
Correction to: Survey of grapevine pathogens in Pakistan
}

\section{Sunniya Rasool ${ }^{1}$ - Shagufta $\mathrm{Naz}^{1} \cdot$ Adib Rowhani $^{2}$ - Alfredo Diaz-Lara ${ }^{2} \cdot$ Deborah A. Golino $^{2} \cdot$ Kristen D. Farrar $^{3}$. Maher Al Rwahnih ${ }^{2}$}

Published online: 17 April 2019

(C) Società Italiana di Patologia Vegetale (S.I.Pa.V.) 2019

\section{Correction to: Nat Hazards}

https://doi.org/10.1007/s42161-019-00263-0

The article was published with a spelling error in to the first listed author. The author group wishes readers to know that the correct name should read Sunniya Rasool and not the former. The original article has been corrected.

Publisher's note Springer Nature remains neutral with regard to jurisdictional claims in published maps and institutional affiliations.

The online version of the original article can be found at https://doi.org/ 10.1007/s42161-019-00263-0

Shagufta Naz

malrwahnih@ucdavis.edu

Maher Al Rwahnih

drsnaz31@hotmail.com

1 Department of Biotechnology, Lahore College for Women

University, Lahore 54000, Pakistan

2 Department of Plant Pathology, University of California-Davis, Davis, CA 95616, USA

3 Foundation Plant Services, Davis, CA 95616, USA 